\title{
ZAKON O SPREČAVANJU ZLOSTAVLJANJA NA RADU
}

U pravni sistem Srbije nedavno je uključen Zakon o sprečavanju zlostavljanja na radu (dalje: Zakon) objavljen u "Službenom glasniku RS“, broj 62/10, koji je stupio na snagu 5. jula 2010. godine, a počeo da se primenjuje 4. septembra 2010. godine.

1. Zakon sadrži: osnovne odredbe, odredbe o pravima, obavezama i odgovornostima poslodavaca i zaposlenih, odredbe o internoj i sudskoj zaštiti, odredbe o nadzoru, kaznene odredbe i prelazne i završne odredbe.

Osnovne odredbe najpre određuju domašaj Zakona propisujući da on važi za sve poslodavce, zaposlene u svim radnim sredinama, lica koja rade ili su na stručnom osposobljavanju i usavršavanju van radnog mesta, volontere i druga lica koja po bilo kom osnovu učestvuju u radu (član 2). One, potom, nameću svakom poslodavcu dužnost da rad organizuje na način kojim se sprečava pojava zlostavljanja i obezbeđuju uslovi u kojima zaposleni neće biti izložen zlostavljanju (član 4). Nameću i zabranu bilo kog vida zlostavljanja na radu ili u vezi sa radom i bilo koje zloupotrebe prava na zaštitu od zlostavljanja (član 5). Značajno je što one definišu zlostavljanje i identifikaciju izvršioca zlostavljanja (član 4).

Pod zlostavljanjem se podrazumeva svako aktivno ili pasivno ponašanje prema zaposlenom ili grupi zaposlenih kod poslodavca koje se ponavlja, a koje za cilj ima ili predstavlja povredu dostojanstva, ugleda, ličnog i profesionalnog integriteta i položaja zaposlenog, i izaziva strah ili stvara neprijateljsko, ponižavajuće ili uvredljivo okruženje, pogoršava uslove rada ili dovodi do toga da se zaposleni izoluje ili navede da na sopstvenu inicijativu prekine radni odnos ili otkaže ugovor o radu, odnosno drugi ugovor (član 6. stav 1).

Izvršiocem zlostavljanja smatra se: poslodavac sa svojstvom fizičkog lica, odgovorno lice kod poslodavca sa svojstvom pravnog lica, zaposleni i grupa zaposlenih kod poslodavca (član 6. stav 2).

Redovni profesor Pravnog fakulteta Univerziteta Union u Beogradu 
Prava, obaveze i odgovornosti u vezi sa zlostavljanjem tiču se poslodavca i zaposlenog.

Poslodavac je dužan: 1) da zaposlenog, pre stupanja na rad, pismenim putem obavesti o zabrani vršenja zlostavljanja i pravima, obavezama i odgovornostima koje ima u vezi sa ovom zabranom, 2) da, tokom rada, u cilju prepoznavanja, prevencije i sprečavanja zlostavljanja, sprovodi mere obaveštavanja i osposobljavanja zaposlenih da prepoznaju uzroke, oblike i posledice zlostavljanja i 3) da zaposlenom koji je izložen zlostavljanju pruži zaštitu predviđenu Zakonom (čl. 7. i 8). Poslodavac odgovara za štetu koju izvršilac zlostavljanja prouzrokuje zaposlenom, ali kad štetu naknadi ima pravo da od izvršioca zlostavljanja zahteva naknadu isplaćenog iznosa (član 9).

Zaposleni je dužan da se uzdrži kako od zlostavljanja tako i od zloupotrebe prava na zaštitu od zlostavljanja, jer u suprotnom odgovara za povredu radne dužnosti, odnosno nepoštovanje radne discipline (član 11. st. 1. i 2). Pošto je o pojmu zlostavljanja bilo reči, ukazaćemo samo na značenje zloupotrebe prava na zaštitu od zlostavljanja. Ovu zloupotrebu čini zaposleni koji je bio ili morao biti svestan da ne postoji osnovan razlog za pokretanje postupka za zaštitu od zlostavljanja, a pokrene ili inicira pokretanje tog postupka sa ciljem da za sebe ili drugog pribavi materijalnu ili nematerijalnu korist ili da drugom nanese štetu (član 11. stav 3). Zaposleni koji sazna za ponašanje za koje opravdano veruje da predstavlja zlostavljanje, ima pravo da kod ovlašćenog lica inicira pokretanje postupka za zaštitu od zlostavljanja (član 14).

Interna zaštita pokreće se obrazloženim zahtevom upućenim poslodavcu. Zahtev može podneti zaposleni koji smatra da je izložen zlostavljanju, a uz njegovu pismenu saglasnost i predstavnik sindikata ili zaposlenih, kao i lice nadležno za bezbednost i zdravlje na radu (član 13). Pravo na podnošenje zahteva zastareva u roku od šest meseci od dana kada je zlostavljanje učinjeno (član 22. stav 1).

Po prijemu zahteva poslodavac je dužan da u roku od tri dana strankama u sporu predloži posredovanje kao način rešavanja spornog odnosa. Posredovanje može u zahtevu predložiti i sam zaposleni. Na predlog poslodavca, strane u sporu sporazumno određuju ili biraju (sa utvrđenog spiska) centralnog posrednika, koji je dužan da postupa nezavisno i nepristrasno (čl. 15. i 16).

Postupak posredovanja je hitan i zatvoren za javnost, osim za predstavnika sindikata. Način sporazumevanja utvrđuju strane u sporu, a ako ne postignu saglasnost, posrednik sprovodi postupak na način koji omogućava svakoj strani da se izjasni o navodima i argumentima druge strane, svejedno da li su oni izneti u posebnim ili zajedničkim razgovorima (čl. 17. i 18). 
Postupak posredovanja okončava se u roku od osam radnih dana od dana određivanja, odnosno izbora posrednika: 1) zaključenjem pismenog sporazuma strana u sporu, 2) odlukom posrednika da se postupak obustavi (zato što nema izgleda da se postigne sporazum) i 3) izjavom strane u sporu da odustaje od daljeg postupka, a iz opravdanih razloga može se produžiti maksimalno 30 dana (član 19).

Smatra se da postupak posredovanja nije uspeo: 1) ako strane u sporu ne odrede, odnosno ne izaberu posrednika u roku od tri dana od prijema predloga i 2) ako se okonča odlukom o obustavi ili izjavom o odustajanju (član 20. stav 1).

Sporazum sadrži mere za prestanak zlostavljanja, odnosno isključenje mogućnosti njegovog nastavljanja, kao i način uređivanja daljih odnosa strana u sporu, a može da sadrži i preporuke poslodavcu koje on radi sprovođenja sporazuma valja da preduzme (član 21).

Ako posredovanje ne uspe, a postoji osnovana sumnja da je zlostavljanja ili zloupotrebe prava na zaštitu od zlostavljanja bilo, poslodavac je dužan da pokrene postupak utvrđivanja odgovornosti zaposlenog za povredu radne obaveze, odnosno nepoštovanje radne discipline, u skladu sa zakonom. Ako se njegova odgovornost utvrdi, poslodavac, pored sankcije propisane zakonom, može da izrekne i jednu od sledećih mera: 1) opomenu, 2) udaljenje sa rada od četiri do trideset radnih dana bez naknade zarade i 3) trajni premeštaj u drugu radnu okolinu na iste ili druge poslove, odnosno na isto ili drugo radno mesto. Ukoliko zaposleni kome je izrečena neka od ovih mera u roku od narednih šest meseci ponovo izvrši zlostavljanje, poslodavac mu može otkazati ugovor o radu, odnosno izreći meru prestanka radnog odnosa (član 23).

Premeštaj u drugu radnu okolinu i udaljenje sa rada uz naknadu zarade, poslodavac može zaposlenom koji se tereti za zlostavljanje izreći i pre okončanja postupka ako zaposlenom koji je izložen zlostavljanju, prema mišljenju službe medicine rada, preti neposredna opasnost od nastanka nenaknadive štete (član 24).

Zaposleni kome, prema mišljenju službe medicine rada, preti neposredna opasnost po život i zdravlje, ima pravo da odbije da radi ako poslodavac preventivno ne primeni meru premeštaja u drugu radnu okolinu, odnosno meru udaljenja sa rada uz naknadu zarade, s tim što je dužan da o tome bez odlaganja obavesti inspekciju rada. Čim se primeni jedna od ovih mera, zaposleni je dužan da se vrati na rad. Dotle mu pripada naknada zarade u visini prosečne zarade koju je ostvario u prethodna tri meseca. Zbog ovog odbijanja rada zaposlenom se ne može otkazati ugovor o radu, odnosno izreći prestanak radnog odnosa (član 26). 
Pokretanje postupka za zaštitu od zlostavljanja ne može biti razlog da se zaposleni: stavi u nepovoljniji položaj, pozove na bilo koju odgovornost, liši radnog odnosa ili proglasi viškom (član 27. stav 1).

Zaposleni za koga se utvrdi da je zloupotrebio pravo na zaštitu od zlostavljanja, ne uživa ovu zaštitu (član 27. stav 3).

Pravila ponašanja u vezi sa prevencijom i zaštitom od zlostavljanja na radu propisuje ministar (član 28). On je to učinio Pravilnikom o pravilima ponašanja poslodavaca i zaposlenih u vezi sa prevencijom i zaštitom od zlostavljanja na radu (dalje: Pravilnik), koji je objavljen u „Službenom glasniku RS“, broj 62/10.

Sudsku zaštitu pokreće tužbom zaposleni koji smatra da je izložen zlostavljanju. Tužba se podnosi protiv poslodavca i može biti direktna ili naknadna. Direktna tužba se podnosi bez prethodnog obraćanja poslodavcu (član 29. stav 1. u vezi sa članom 14. stav 2), u roku od šest meseci od dana kada je poslednja radnja zlostavljanja učinjena (član 22. st. 1. i 2). Naknadna tužba se podnosi posle bezuspešnog okončanja postupka posredovanja, odnosno ako zaposleni ne bude zadovoljan ishodom interne zaštite, i to u roku od 15 dana od dana dostavljanja odluke o obustavi postupka, obaveštenja o odustajanju od daljeg postupka ili odluke o neizricanju mere, odnosno izricanju neadekvatne mere (član 29. stav 2).

Ni direktnom ni naknadnom tužbom za zaštitu od zlostavljanja, zaposleni ne može pobijati pojedinačni akt poslodavca kojim je rešeno o pravu, obavezi ili odgovornosti zaposlenog iz radnog odnosa, zato što taj akt može pobijati po opštim propisima o sudskoj zaštiti u radnom ili upravnom sporu.

Pošto je ovde reč o radnom sporu (član 29. stav 1), nadležni sud je, po članu 22. stav 3. Zakona o uređenju sudova, osnovni sud.

U ovom sporu primenjuju se procesna pravila koja važe u svim radnim sporovima ako specijalnim pravilima Zakona nije drukčije određeno. A evo šta je drukčije određeno:

Zaposleni u tužbi može da zahteva: 1) utvrđenje da je pretrpeo zlostavljanje; 2) zabranu ponašanja koje predstavlja zlostavljanje, zabranu daljeg zlostavljanja i zabranu ponavljanja zlostavljanja; 3) izvršenje radnje radi uklanjanja posledica zlostavljanja; 4) naknadu materijalne i nematerijalne štete; 5) objavljivanje presude donete po svim prethodnim zahtevima (član 30).

Ako je u toku postupka tužilac učinio verovatnim da je zlostavljanje izvršeno, teret dokazivanja da nije bilo zlostavljanja pada na poslodavca (član 31). 
Zbog hitnosti postupka koji važi i u ovom sporu, sud je dužan da tužbu sa prilozima dostavi tuženom na odgovor u roku od 15 dana od dana prijema tužbe (član 32).

Kao i u ostalim radnim sporovima, i u ovom sud može po predlogu stranke ili po službenoj dužnosti, odrediti privremene mere radi sprečavanja nasilnog ponašanja ili otklanjanja nenadoknadive štete, $u$ koje spadaju naročito - zabrana približavanja i zabrana pristupa u prostor rada zaposlenog. Za donošenje rešenja o privremenoj meri dovoljna je verovatnoća da je zaposleni izložen zlostavljanju (član 33).

Nadzor nad sprovođenjem ovog zakona vrši inspekcija rada, a kad je reč o javnim službenicima - upravna inspekcija (član 34).

Kaznene odredbe tiču se novčanih kazni koje se izriču poslodavcu sa ili bez svojstva pravnog lica, kao i odgovornom licu kod poslodavca.

Prelazne i završne odredbe odredile su rok za donošenje Pravilnika, dan stupanja na snagu Zakona i početak primene Zakona.

2. Zakon je valjan normativni okvir za suzbijanje zlostavljanja na radu, a lica izložena ovoj pošasti imaće pouzdan oslonac u njegovim normama. To, međutim, ne znači da je Zakon bez mana. Mana ima, a njih je važno uočiti da bi bile noveliranjem otklonjene ili tumačenjem ublažene. Evo najkrupnijih:

Zakon, u članu 5, zabranjuje i zlostavljanje i zloupotrebu prava na zaštitu od zlostavljanja. Dajući im jednak značaj, on zlostavljanje i zloupotrebu zaštite od zlostavljanja proglašava povredom radne dužnosti, odnosno narušavanjem radne discipline, zbog čega se mogu izreći sankcije, uključujući i otkaz ugovora o radu, odnosno prestanak radnog odnosa. Zakon donet radi suzbijanja zlostavljanja ne treba da pridaje toliki značaj zloupotrebi prava na zaštitu od zlostavljanja, jer time žrtvama zlostavljanja preti zloupotrebom prava na zaštitu. Pretnja nije bezazlena, pošto o odgovornosti za zloupotrebu (baš kao i o odgovornosti za zlostavljanje) odlučuje poslodavac (odnosno lice koje on ovlasti) na osnovu člana 23. st. 2. i 3. Zakona. A on je, prema podacima resornog ministarstva, u 95 odsto slučajeva zlostavljač. Pošto se od poslodavca ne može očekivati da samog sebe proglasi zlostavljačem, njemu se otvara mogućnost da zlostavlja i zloupotrebom zabrane zloupotrebe prava na zaštitu od zlostavljanja. Ova mana može biti uklonjena odredbom da sankcije prema poslodavcu (odnosno njegovom organu poslovođenja) izriče eksterni organ, odnosno organ imenovanja ili postavljenja. Valjalo bi razmotriti brisanje odredbe o zloupotrebi prava na zaštitu od zlostavljanja, jer ona zlostavljače ohrabruje. 
Prema članu 6. stav 1. Zakona, zlostavljanje je aktivno ili pasivno ponašanje „koje se ponavlja“. Kad je radnja zlostavljanja trenutna, ponovljeno zlostavljanje je lako identifikovati. Ali nije kad se zlostavljanje vrši trajnom radnjom, iz dana u dan ili iz nedelje u nedelju. Tada na „ponovljeno zlostavljanje" treba čekati dugo, a to ne odgovara suštini zabrane i potrebi brzog i efikasnog suzbijanja zlostavljanja. Zato bi kod trajnog zlostavljanja ponovljenu radnju trebalo računati već od drugog dana po započinjanju.

$\mathrm{Na}$ osnovu člana 28. Zakona, ministar nadležan za rad doneo je Pravilnik koji daje korisna uputstva za sprovođenje Zakona. Ali, i iritira jer član 13. predviđa da se zlostavljanjem ne smatra: 1) pojedinačni akt poslodavca o pravima, obavezama i odgovornosti iz radnog odnosa, protiv kojeg zaposleni ima pravo na zaštitu propisanu zakonom; 2) uskraćivanje i onemogućavanje prava utvrđenih zakonom, opštim aktom i ugovorom o radu, čija se zaštita ostvaruje u postupku kod poslodavca i pred nadležnim sudom; 3) svako neopravdano pravljenje razlike ili nejednako postupanje prema zaposlenom po bilo kom osnovu diskriminacije po kome se zaštita obezbeđuje u skladu sa posebnim zakonom. Pojedinačni akti, radnje uskraćivanja ili onemogućavanja prava i diskriminatorski postupci poslodavca najčešći su instrumenti zlostavljanja. Ako se na ovaj način narušava dostojanstvo, ugled, lični i profesionalni integritet, zdravlje i položaj, izaziva strah, stvara neprijateljsko, ponižavajuće ili uvredljivo okruženje ili ugrožava poredak rada, onda Pravilnik ne može pomoći da se izbegne odgovornost za vršenje zlostavljanja. Pojam zlostavljanja je članom 6. Zakona dobro postavljen i ne pruža priliku za bilo kakve redukcije.

Slutimo da je član 13. Pravilnika proizašao iz odrebe člana 29. stav 3. Zakona. Ako jeste, onda tu odredbu nije dobro razumeo. Ona (u prvoj rečenici) predviđa da tužbom radi sprečavanja zlostavljanja zaposleni ne može pobijati zakonitost pojedinačnog akta kojim je poslodavac rešavao o pravima, obavezama i odgovornostima iz radnog odnosa. Naravno da ne može. Za to služi tužba za poništaj pojedinačnog akta u postupku sudske zaštite koji je predviđen članom 195. Zakona o radu. U tom postupku on će biti poništen ako sud utvrdi da je donet u patologiji zlostavljanja a ne u higijeni primene prava. $\mathrm{O}$ tome svedoči višedecenijski stav sudske prakse da šikanozni (dakle, zlostavljajući) razlozi, makar koliko bili prikriveni, uvek vode poništavanju pojedinačnog akta koji je predmet radnog spora. Taj stav se može prepoznati iz ove dve sudske odluke:

„U tužbi za poništaj rešenja o prestanku radnog odnosa, sud ispituje istinitost činjenica na osnovu kojih je ona doneta. Pošto je radno mesto tužioca ukinuto prividno, samo radi toga da mu prestane radni odnos, pobijano rešenje je šikanozno, pa zbog toga i nezakonito." (Presuda Vrhovnog suda Srbije Rev 1/69 od 24. 2. 1969. godine) 
„Sud se ne može upuštati u celishodnost odluke koja se u radnom sporu pobija. Međutim, iza celishodnosti ne mogu se zaklanjati šikanozni motivi. Tada je istina u šikani a ona uvek vodi poništavanju pobijane odluke." (Rešenje Suda udruženog rada Srbije 907/80 od 9. 6. 1980. godine)

Prema tome, ako se pojedinačni akt poslodavca o pravu, obavezi ili odgovornosti iz radnog odnosa ne može pobijati tužbom radi zaštite od zlostavljanja, može tužbom za poništaj. A ako taj akt, zato što je zlostavljajući, bude poništen, onda bi se mogao pokrenuti i postupak utvrđivanja odgovornosti za njime učinjeno zlostavljanje. Nažalost, Zakon o ovome nije vodio računa. Da jeste, pravo na podnošenje zahteva, odnosno tužbe za zaštitu od zlostavljanja ne bi vezao za rok od svega šest meseci (član 14. stav 2. u vezi sa članom 22. st. 1. i 2). Pravilnik je bio još nemarniji, jer je članom 13. tačka 1. predvideo da se pojedinačni akt poslodavca ne može smatrati zlostavljanjem! Ova mana može biti otklonjena delotvornim tumačenjem člana 29. stav 3. Zakona, izmenom člana 22. stav 1 . Zakona i brisanjem člana 13. Pravilnika.

Prema članu 31. Zakona, ako je u toku postupka tužilac učinio verovatnim da je zlostavljanje izvršeno, teret dokazivanja da ga nije bilo pada na poslodavca. Postoje tri stepena dokazanosti: verovatnoća, ubeđenje i izvesnost. Verovatnoća je utisak o postojanju neke činjenice. Ubeđenje da neka činjenica postoji, rezultat je ocene izvedenih dokaza. Izvesnost je apsolutna sigurnost u postojanje određene činjenice. Ukoliko tužilac (dakle, zaposleni) uspe da kod suda stvori utisak o postojanju zlostavljanja, on se preobražava u pretpostavku koju tuženi (dakle, poslodavac) može obarati protivdokazima. Ako u tome ne uspe, sud, primenom pravila o teretu dokazivanja, presuđuje u korist tužioca. A u toj situaciji, presudu o postojanju zlostavljanja zasniva samo na verovatnoći. Najniži stepen dokazanosti nikako ne odgovara težini odluke da je zlostavljanje učinjeno. Ova mana može biti otklonjena brisanjem člana 31. Zakona.

Zakon se nije odredio prema postupku koji se povodom zlostavljanja na radu vodi pred arbitrom Agencije za mirno rešavanje radnih sporova. A trebalo je da se odredi zbog slučajeva kad o nekom zlostavljanju rešava i sud i Agencija.

Kada se ove mane otklone, dobar Zakon postaće još bolji. 